\title{
On the Systematic Innovation and Transformation of Guangzhou Convention \& Exhibition Industry
}

\author{
AmyMya Menghua LIU1, Min $\mathrm{ZHAO}^{2,}{ }^{*}$ and Shun $\mathrm{YI}^{3}$ \\ ${ }^{1}$ South China Business College, Guangdong University of Foreign Studies, Guangzhou, P.R.C \\ ${ }^{2}$ South China Business College, Guangdong University of Foreign Studies, Guangzhou, P.R.C \\ ${ }^{3}$ Zhao Qing University, Zhaoqing, P.R.C) \\ ${ }^{*}$ Corresponding author
}

Keywords: Business travelers, Exhibition well-known city, Institutional innovation, Destination promotion, Exhibition management mode.

\begin{abstract}
Through inspections of famous convention and exhibition cities worldwide, "Hong Kong's all-round development exhibition", "Shanghai inbound tourism model based on the conference ambassador", and "double drive model in Xiamen", we found out that convention and exhibition are all encouraging large and medium-sized exhibitions, derive a conference, or use meetings to promote a professional exhibition in the city. The close integration of the exhibition and conference activity is an important trend in the development of the convention and exhibition industry. With Chinese economy returning to the new normal, the institutional innovation of the exhibition industry is even more imminent. Although Guangzhou has paid too much attention to the exhibition having led to some problems, the recent trend toward the industrialization of the conference has become increasingly apparent. Institutional innovations have also been considered in terms of statistics indicators of convention and exhibitions, spatial distribution, competent organizations design and some international experiences have been used in the promoting convention and exposition as attractions and Guangzhou as a destination for business travelling.

As China's economy gradually returns to the new normal, economic growth has slowed down significantly, and there is a serious overcapacity in basic industries. In the future, China's economic growth will become very weak. Faced with the severe economic development situation, Premier Li Keqiang firstly promoted the "New Economy" to the national long-term strategic plan on March 5, 2016. From the perspective of world experience, the rapid development of the new economy has led to the formation of a strategic modern service industry. As a typical modern service industry, convention tourism not only has its own characteristics of high profitability, but also can stimulate the development of other industries. At the same time, all departments of tourism industry are undergoing in-depth technological innovation and the similar industries are undergoing transformation and upgrading. As a dazzling "sunrise industry" in the new century, the exhibition tourism industry is extremely connected and has a very wide range of economic themes, which can bring enormous economic and social effects to urban development. From a global point of view, international metropolises are basically convention and exhibition cities such as Hong Kong, Tokyo, London, Singapore, Paris and New York. Since the 1990s, the Chinese exhibition industry has developed rapidly. Guangzhou has always been committed to developing the exhibition economy to enhance the city's image and achieve economic restructuring and upgrading especially for displaying import and export products. As China's current economic development features "medium-high speed, excellent structure, new motivation, and multiple challenges", the development of the exhibition industry has undergone tremendous adjustments. In this era of both opportunities and challenges, innovation and development of Guangzhou exhibition industry is significant to its transformation and upgrading.
\end{abstract}

\section{General Introduction to Exhibition and Convention Industry in China}

According to the China Conference and Exhibition Economic Research Association, the pace of development of China's exhibition industry has slowed down significantly in 2015, and it has 
entered the period of "finishing cultivation" in the new normal period. In 2016, a total of 9283 exhibitions were held in China, totaling an exhibition area of 117.98 million square meters, which is still growing. Top 10 exhibition cities ${ }^{1}$ are Shanghai $\left(1511.55 \mathrm{~m}^{2}\right)$, Guangzhou $\left(861 \mathrm{~m}^{2}\right)$, Chongqing $\left(749 \mathrm{~m}^{2}\right)$, Beijing $\left(520.10 \mathrm{~m}^{2}\right)$ and Tianjin $\left(346 \mathrm{~m}^{2}\right)$, Dongguan $\left(340 \mathrm{~m}^{2}\right)$, Chengdu $\left(310.4 \mathrm{~m}^{2}\right)$ and Shenyang $\left(310 \mathrm{~m}^{2}\right)$, Wuhan $\left(307 \mathrm{~m}^{2}\right)$ and Qingdao $\left(295 \mathrm{~m}^{2}\right)$. In 2016 , the top ten cities in the exhibition are still Shanghai, Guangzhou, Beijing, Tianjin, Chengdu and Wuhan. Held a total of 4022 well-known exhibitions in 2017, China's exhibition covered about 134.7 million square meters, with the micro growth. Host of the top five domestic exhibition city are Shanghai $\left(2568 \mathrm{~m}^{2}\right)$, Guangzhou $\left(1487 \mathrm{~m}^{2}\right)$, Beijing $\left(990 \mathrm{~m}^{2}\right)$, Shenzhen $\left(534 \mathrm{~m}^{2}\right)$ and Zhengzhou $\left(403 \mathrm{~m}^{2}\right)$; the exhibition area of Jinan, Nanjing, Tianjin and Dongguan has also been added to over 2 million square meters of 15 cities. Overall, the exhibition area of more than 20 million square meters is Shanghai, Guangzhou; the exhibition area of Shandong ranked in the third, and exhibitions in Sichuan grow the fastest. Yet, the Guangdong exhibition is mainly concentrated in the two central cities, Shenzhen and Guangzhou.

As a coincident sector of the tourism industry and the exhibition industry, the conference industry has been increasingly valued and developed rapidly in recent years. According to the latest statistics from the International Conference and Convention Association (ICCA), the world held about 400,000 conferences each year, with an overall cost of over US $\$ 300$ billion. Obviously, the international conference market has great economic potential, and thus the world has vigorously developed the conference industry. The United States has always been a leader in the national conference market, and it has a great advantage in terms of air passenger traffic and the number of hotel guests in international conferences. From the point of view of the city, Paris has hosted about 400 meetings each year. This not only makes the international conferences that it receives every year rank among the top three cities in the world, but also brings it a huge income. ICCA estimates that $15 \%$ of the global tourism industry's share in 2015 will come from the international conference market. Some of the top 10 international conferences in the rankings changed in 2016: Poland and Argentina won 200 international conferences and entered the top 20 for the first time. The number of international conferences undertaken by China has increased significantly compared to 2015, with an increase of 77 games. The international rankings and influence in the Asia-Pacific region are comparable to Japan (see the table below).

Table 1. Number ranking of 2015-2016 world international conferences

\begin{tabular}{|llll|}
\hline 2016 & Country & $\begin{array}{l}2015 \\
\text { Ranking }\end{array}$ & Amount \\
\hline 1 & America & 1 & 925 \\
2 & Germany & 2 & 667 \\
3 & Britain & 3 & 582 \\
4 & France & 5 & 522 \\
5 & Spain & 4 & 572 \\
6 & Italy & 6 & 504 \\
7 & China & 8 & 333 \\
8 & Japan & 7 & 355 \\
9 & Holland & 9 & 333 \\
10 & Canada & 10 & 308 \\
\hline
\end{tabular}

Table 2. 2015-2016 China international conference number distribution and top 10 cities

\begin{tabular}{|lllll|}
\hline $\begin{array}{l}2016 \\
\text { ranking }\end{array}$ & City & Amount & $\begin{array}{l}2015 \\
\text { ranking }\end{array}$ & Amount \\
\hline 1 & Beijing & 113 & 1 & 95 \\
2 & Shanghai & 79 & 2 & 55 \\
3 & Chengdu & 20 & 5 & 13 \\
4 & Xi 'an & 20 & 6 & 11 \\
5 & Nanjing & 18 & 4 & 16 \\
6 & Guangzhou & 16 & $*$ & $*$ \\
\hline
\end{tabular}




\begin{tabular}{|lllll|}
7 & Wuhan & 15 & 8 & 9 \\
8 & Hangzhou & 12 & 3 & 27 \\
9 & Shenzhen & 12 & 7 & 10 \\
10 & Suzhou & 12 & 10 & 7 \\
\hline
\end{tabular}

In the recent ten years, the conference industry has successively flourished in major cities and tourist cities in China (see Table 2 for details), according to the 2016 China Conference Industry Conference (CMIC) survey; places like Beijing, Shanghai, and Chengdu are the most popular conference destinations in China with the largest number of international conferences, the most attractive attractions, and the best development potential.

In 2016, Guangzhou strengthened its bid for international conferences and achieved significant growth. However, according to ICCA and CMIC statistics, the average of the 2001-2016 international conferences in China reached 263, and 16 international conferences in 2016. Guangzhou did not occupy $10 \%$ of the China International Conference, which still have large difference from the well-known conference cities like Beijing, Shanghai, Chengdu, Xian and Nanjing.

Based on the above, one can draw a conclusion that the cities that have developed well in both the conference and exhibition are Shanghai, Beijing, Chengdu, Wuhan and Tianjin. There are reasons to be an exhibition well-known city. Conference cities such as Xiamen and Hangzhou have special significance for cities that overlook conference tourism such as Guangzhou, because conference tourism does not exert its economic and social benefits, and development is still in its infancy. Fortunately, in 2017, Guangzhou had increased the support for the conference tourism industry, continued doing more international conferences, and strengthened the conference tourism industry, which will help Guangzhou become a truly "famous exhibition city".

Unlike the stagnant conference industry, Guangzhou has its exhibition development in both domestic and international market. According to Guangdong Council for the Promotion of International Trade, in 2016 Guangzhou has 146 professional exhibition corporations possessing the capacity to organize exhibition, in which 25 companies include China Foreign Trade and Guangzhou Exhibition Corp., Guangzhou Poly Jinhan Exhibition Co. Ltd., UBM Public Limited Company, UBM Trust Co Ltd, and Guangzhou Yi Wu International Exhibition Co., Ltd. are certified by UFI (International Exhibition Association). In respect of the talent pool, Guangzhou has set up a total of 30 universities and colleges for exhibitions and exhibitions, and has trained about 1,000 graduates from various levels of undergraduates, masters, doctors and specialists each year. On the whole, the development of the conference industry and exhibition industry in Guangzhou was once seriously unbalanced. The traditional development mode of "heavy exhibition and light conference" in Guangzhou is very unfavorable to the transformation and upgrading of the convention and exhibition industry, and the current situation has changed.

\section{Investigation: The Transformation Model of Exhibition Industry and Innovative Promotion of Tourism Destination}

It is a common practice for the developed countries and regions to strengthen the unified management, coordinated development and support of the exhibition and tourism through the conference industry. In the development of regional economy, there is no lack of the international experience of the government to carry out the marketing of destination and the innovation of the system.

\section{A Typical Model for the Development of Convention and Exhibition Industry}

The German Conference Bureau (GCB) is responsible for the bid for the German conference, promotion of the tourism market, and service work. The exhibition industry is coordinated and supported by the AUMA (German Trade and Exhibition Association), an authoritative association. In China, Hangzhou Convention and Exhibition Center under the Tourism Administrations promoted it as the city for "global conference tourism", which enabled Hangzhou to obtain the opportunity to host the G20 summit. At the same time, its exhibition center also won the right to 
host more exhibitions; Beijing, through Tourism Development Office and professional associations, promotes the development of its "high-end tourism conference industry", optimizes the resources allocation of the exhibition industry, and competes fully in the industry, so that it also has a relatively large competitive advantage in the domestic exhibition industry. The following countries and regions have been conducted field interviews with competent authorities, and their experience in the development of the exhibition industry is worth learning from.

Hong Kong's All-round Development Convention and Exhibition Industry Model. Hong Kong has a long history of exhibition development, and the exhibition industry management system is very complete. Hong Kong Tourism Association was established in 1957 and was fully funded by the government. In order to promote international conferences, exhibitions and conventions and tourism, Hong Kong Tourism Association established 17 overseas offices in 1986, eventually achieving all-round development of the convention and exhibition industry. Since 2008 Hong Kong Tourism Board has newly established Hong Kong Convention and Exhibition Development Department. There are three offices to provide specialized services for corporate meetings, incentive travel, large-scale conferences and exhibitions. In recent years, the Tourism Bureau commissioned representatives and actively promoted conferences and exhibitions to India, Japan, United Kingdom, and United States, which is of outstanding significance. Hong Kong's exhibition industry operations are mainly driven by the Hong Kong International Exhibition Center under the auspices of the Hong Kong Trade Development Council. Each year, it attracts investment from Asian commercial cities such as the Mainland developed cities and Singapore, attracting participation in Hong Kong Electronics Fair, International Wine Fair, Toy Fair, and Book Fair. Recently Hong Kong actively promoted its cooperation within Bay area, Guangdong, Hong Kong and Macao.

Shanghai Inbound Tourism Model Based on the Conference Ambassador. Shanghai is an internationally recognized destination for Chinese conferences, and is also one of the first regions in China to promote conferences and accurately position the conference industry. Due to the similarities in the international trade between Shanghai and Guangzhou, the "Shanghai model" is particularly worthy of discussion in Guangzhou. Since 2006, the "Shanghai Conference Ambassador" has always been a major task of the Shanghai Municipal Tourism Bureau's International Promotion Office. Shanghai Promotion Office believes that the conference tourism development model under the "Conference Ambassador System" requires less investment (300,000 budgets per year) and provides assurance services such as information consultation, publicity and promotion, cooperated with experts to compete in the international arena and vie with each other. So far, they attracted enough international professional conferences to enter Shanghai to complete the promotion of inbound tourism. The Shanghai Tourism Bureau's Office for International Promotion and the outstanding figures from various industries in the city have joined hands to plan how to build Shanghai into a new conference and tourism destination. It also greatly encourages the Shanghai Tourism Promotion Office to consider the positioning of Shanghai's tourism image and promotion strategy of supporting services. By 2014, the Shanghai conference tourism has entered a period of stable development. The 2016 International Conference of Ministers of the G20 Summit and other international conference organizing committees has all taken the initiative to Shanghai. While promoting the attractiveness of the conference in Shanghai, the International Promotion Office also introduced to the world the Expo Center, exhibition center and professional exhibition preparation unit under the leadership of the Shanghai Municipal Commission of Commerce.

"Xiamen Double Drive Model" under the Convention and Exhibition Bureau. The "Xiamen City Convention and Exhibition Bureau" is the result of the reform of China's tourism system. Since 2011, it has developed an exhibition plan and a conference plan to develop the exhibition industry in both directions. In 2015, the economic efficiency of the Xiamen convention and exhibition industry was further improved. There were 6,328 host conferences and 1.35 million foreign participants. For three consecutive years, the conference industry exceeded $50 \%$ of the overall convention and exhibition economic benefits (The total revenue of the exhibition industry 
was 31.804 billion Yuan, accounting for approximately 9\% of the city's GDP) and it achieved a new development and a new leap under the "new normal."

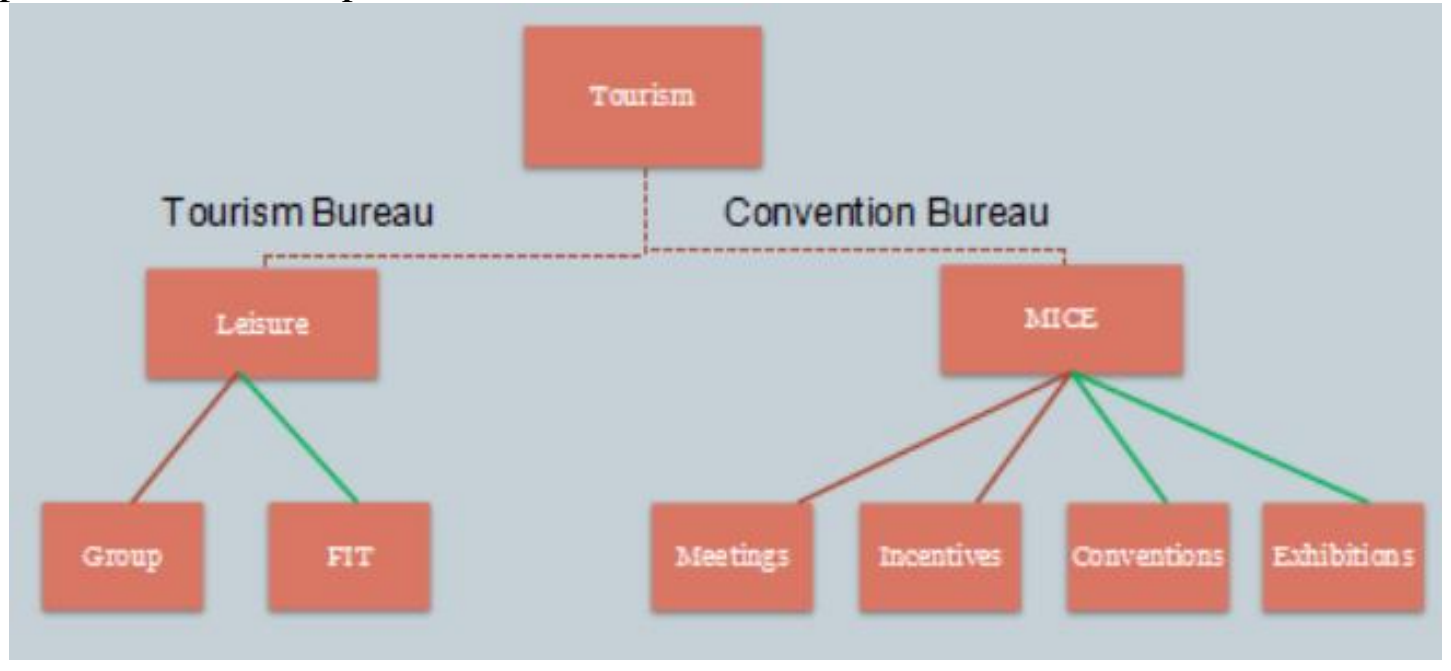

Figure 2. Management concept of "Mega Tourism" in Xiamen: a relationship between the convention bureau and the tourism bureau

Like the convention and exhibition industry in developed regions, the rapid development of the Xiamen conference tourism mainly lies in adopting the advanced system of international convention and exhibition management (Weber, 2002). In 2012, for the first time, Xiamen organized leisure travel, convention and exhibition business in blocks, but the municipal party committee also has leadership to manage them in a unified manner. For the details of organization structure and tourism management concept of Xiamen Double Drive Model, please read the photo above.

Xinjiang and Sichuan's "Exhibition Bureau Model". In the innovation of the domestic convention and exhibition system, the Xinjiang International Expo Administrations was established earlier. In 2011, it set up six departments, including the exhibition affairs and investment invitation and exhibition, around the "sia-Europe Expo" Sichuan Bureau of Exhibition Affairs (2014) focuses its work on the "estern China International Fair CIF) with exhibitions and government marketing as its main tasks. It has 9 departments including the Western China International Fair Office, the Exhibition Office, the Foreign Liaison Office, and the Sichuan Exhibition Brand Promotion.

\section{The Enlightenment from the System Innovation of Exhibition Industry to the Promotion of Destinations in Convention and Exhibition City}

The industry management of the exhibition industry in most of the exhibition cities in China is similar to Hong Kong. The exhibition industry developed under the Ministry of Commerce. However, its tourism bureau did not learn from the experience set by the Hong Kong Tourism Board's conference promotion representatives and organizations. They neglected the principle of simultaneous development of conferences and exhibitions, cooperation in division of labor, and unified management. They did not exert the ability to promote tourism destinations, and ignored the synergy effects and economic multiplier effects of tourism-related industries. So far, despite the rapid growth of Guangzhou's international conferences and breakthroughs in conference tourism, it is still insufficient compared with other destionations in the ICCA and UFI list.

Among the MICE management agencies of Shanghai, Xiamen, Beijing, Zhuhai, Xiamen using parallel Bureau of Exhibitions and Tourism Bureau, focusing on the development of leisure tourism and business tourism at the same time; The MICE tourism policy and government promotion under the guidance of the Shanghai Municipal Tourism Administrations were heavily invested in the early stage; there was a special conference ambassador promotion team, a powerful Shanghai Exhibition Industry Association, and a business and conference council that provided long-term intellectual support for the Tourism Bureau. Its tourism and convention policies are all devoted to creating an international convention and exhibition metropolis. As far as Beijing is concerned, it has vigorously built large-scale conference (1000 people) resort hotels in the suburbs and has received strong 
support from the government. It is most worthy of studying for the suburbs of Guangzhou. In addition, the Business Professional Association under the Beijing Municipal Commission of Tourism Development directly provides guidance to convention and exhibition companies. The non-profit organization-style exhibition management reflects the city's mission of the convention and exhibition. The policy orientation and media plan for the development of high-end business tourism in Beijing are also worth pondering. Under the background of new media such as Internet celebrity and self-media, the media plan for Guangzhou's city image should be launched from the aspects of WeChat, Weibo, and live coverage of large-scale exhibitions and conferences.

The Exhibition Bureau established by Sichuan and Xinjiang to promote well-known exhibitions has played a significant role in promoting the early development of the convention and exhibition industry. As China's convention and exhibition industry has entered the era of fine work, Xiamen and Zhuhai's convention and exhibition administration covering the conference development department are more adaptable to the institutional innovation of the convention and exhibition industry in today's convention and exhibition cities.

\section{Case Study: Industrial Systematic Innovation in Transformation and Development of Guangzhou Convention \& Exhibition}

From the "MICE Tourism Resource Owners (Organizations), Core Promoters of Conference Industry, Exhibition Policies, ules and Regulations", China's conference tourism and exhibition operations are under two departments. The decentralized MICE industry management is very unfavorable to closely coordinated development of the convention and exhibition industry.

\section{Analysis of Development Status and Problems of Guangzhou Convention and Exhibition Industry}

Excessive Tendencies to the Exhibition Industry, Serious Loss of Meeting Market. The development of the convention and exhibition industry in Guangzhou is slightly uneven. The conference industry has lagged behind the local exhibition industry and also lags behind other convention and exhibition cities. Due to the lack of landing of well-known international conferences in Guangzhou, lack of effective government marketing, and the fact that the international conference market is still in its infancy, it has led to the loss of local conference visitors and the overlook the guests' needs

Urgent Need for Industrial Upgrading, and for the Provincial and Departmental Professional Agencies in the Exhibition Industry. The development of exhibition industry in Guangzhou was weak. During the period from 2011 to 2015, the transaction volume of the Canton Fair continued to decline. The rate of decline in the last two years was about $10 \%$, which was the same as the declining trend of China's GDP growth rate. The traditional exhibition industry urgently needs industrial upgrading and rational deployment. The dislocation and absence of macro management in the exhibition industry in Guangzhou restrict the balanced development of the Guangzhou convention and exhibition industry. Due to the large number of departments involved in the exhibition and the difficulty of coordination, Guangzhou lacked a unified management organization for the exhibition industry. At the same time, due to the fragmented management of the administrative departments, the industry competition is not sufficient and the allocation of industry resources is not optimized. Guangzhou is in urgent need of provincial and departmental professional agencies in the exhibition industry to effectively promote industry management and avoid small horse for drawn carts.

Constraints in the Development of the Conference Industry: Backwardness in the System and Lack of Advanced Marketing Methods in Destination. Judging from the current resistance of Guangzhou's development of the conference industry, there are several factors that restrict its development. First, the public's traditional business concept and the rigid government's exhibition management has not meeting the need. Second, there is a lack of specialized conference administration agencies or authoritative industry coordination agencies to conduct unified management. Third, professional personnel serving the conference industry are rather lacking. 
Fourth, government marketing is relatively monotonous, and the conference tourism promotion like tourism exposition is not effective. Fifth, Guangzhou tourism destinations need more recognition from the MICE Tourism Association and the Economic and Trade Conference, expecting more reports from UNWTO, ICCA, UFI, and DMC.

As the frontline of reform and opening up, Guangzhou has developed its foreign business, exhibitions, transportation, and services. The above problems may not have attracted attention in the national similar exhibition cities. Considering the slowdown in the development of exhibitions, our team has called for a stronger system of innovation in the convention and exhibition industry, and institutional issues are one of the major factors constraining economic development. In addition, the conference industry in Guangzhou has the conditions for development. Since 2016, the discussion and research on the innovation of the convention and exhibition industry system that precedes the practice is emerging in Guangzhou.

\section{New Trends in Transformation of MICE Tourism Industry in Guangzhou}

In December 2016, the Chinese People's Political Consultative Conference (CPPCC) held a conference in Guangzhou when the topic of "Industrial Innovation in Guangzhou's MICE tourism, Development and Transformation" received unprecedented attention. The lack of international conferences and suburban exhibitions has also been discussed in depth, THROUGH the efforts of the relevant departments such as the Commerce Committee and the Tourism Bureau, Guangzhou has achieved remarkable success in the promotion of the conference destinations in 2016. It has obtained a total of 410 conferences and 16 ICCA-accredited international conferences. In 2017, Guangzhou held"International Tourism Destination Construction Conference" to demonstrate the determination of Guangzhou to develop the urban tourism and MICE industry transformation; in 2018, it will continue to develop towards the MICE city and tourism economy. The following questions have received a certain level of attention and still in discussion:

Expand Statistical Indicators for Exhibition and Conference Industry. As Guangzhou has always focused on the development of the exhibition industry, the exhibition economic report only uses extensive statistical indicators such as "exhibition area", "number of exhibitions" and "exhibition theme" of the exhibition industry. Therefore, in order to more accurately measure the contribution of the convention and exhibition industry to economic development, special indicators such as "pull economic benefits" and "direct economic benefits" are being considered when formulating relevant statistical indicators for the convention and exhibition industry.

The conference industry, which is in its infancy, is also discussing the experience at the initial stage. (1) The conferences, summits, and investment fairs, (2) incentives tourism (3) advertising promotions, (4) fundraising events organized by star hotels, conference centers, and banquet halls and other conference-defining economic benefits and meeting scales are all included in the statistical category

The Space Transfer of Guangzhou Convention and Exhibition Industry: from the Development of Exhibition Industry in Downtown Area to the Conference Industry and Professional Exhibition in Suburbs. At present, there are many problems in the Guangzhou exhibition management model, and its biggest flaw lies in the fact that in order to highlight the advantages of traditional brands such as the Canton Fair, the government only builds world-class exhibition halls in Guangzhou's CBD area. They plans, sells and serves exhibitors and buyers from various levels of the Ministry of Commerce, the Provincial Department of Commerce, and state-owned exhibition companies. Obviously, the exhibition in Guangzhou was successful and made an unparalleled contribution to Guangzhou's status as a central city during the 13th Five-Year Plan period. In fact, exhibitions held in the heart of the city are generally difficult to develop as exhibition tourism. This is because large-scale exhibitions have strong timeliness and market potential is very limited. On the one hand, during the exhibition period, the city reception faced great challenges. On the other hand, the supporting facilities of the exhibition hall were idle in the off-season. The opportunity cost of the tourism economy that is lost in the idle public facilities in the city center should be taken seriously by Guangzhou. 
In fact, people in the suburbs of Guangzhou, the southern suburbs, the eastern suburbs and the northern suburbs have been thinking about their business functions. Taking the southern suburbs of Guangzhou as an example, Chimelong Resort Hotel can host a 2,000-person conference and provide one-stop service for food, lodging, transportation, travel, entertainment, and conferences. The Phoenix City Hotel (Zengcheng), which is earlier than the Conference Hotel in Nanjiao, has also been famous for hosting 1,000 annual corporate events. The planning of the Guangzhou Baiyun International Convention Center serves the Executive staff and can accommodate world-class financial conferences. The northern suburb of Guangzhou is located in the core area of the airport economic circle. It is the airport gateway of Guangzhou. There are many business hotels such as Huaju Grand Hotel, Pullman Guangzhou Baiyun Airport Hotel, and Crowne Plaza Guangzhou Huadu in 10 kilometers. These hotels have established a suburban business conference hotel market with advanced infrastructure, excellent service, rich and varied catering, diversified conference halls and high-cost rooms. The professional exhibitions in the suburbs can also be seamlessly linked with Guangzhou Baiyun International Airport and meet the efficiency requirements of business travelers who travel to and from Guangzhou many times. At the same time, the administrative department that represents the government's management of destinations and marketing is considering the reception and communication capabilities of the hotels and airports in the suburbs.

The Integration of the Tourism Resources in Guangzhou. The management of tourism in Guangzhou is relatively decentralized. The Guangzhou Municipal Commission of Commerce and the Tourism Administration of Guangzhou manage business exhibition tourism and leisure incentive tourism respectively. However, in fact, the Guangzhou Municipal Business Council is not very good at managing and promoting exhibition tourism for business travel, but is more familiar with general commercial business. They are not as familiar with tourists on business trips away from their hometown, business travelers with high consumption and behaviors as the Tourism Administrations , and yet the traditional tourist bureaus does not know much about the new traveller and professional exhibition companies in urgent need of quality time and a high level of service . Therefore, splitting the market into leisure tourism and business tourism management by two teams led to block management, is not conducive to the integration of Guangzhou's resources, and better development of the tourism economy.

Organization Form of Exhibition Based on Business Development: Preparation for the Convention and Exhibition Administrations. In the process of the government's macro-control and resource allocation, Shanghai, Xiamen, and Hong Kong have reduced administrative participation after the maturity period and moved from the executive to the industry. However, this is not the only choice. There are four forms of exhibition professional organizations that can be used for reference in Guangzhou:

First of all, comparing the organizational models of the four convention and exhibition management agencies, Guangzhou first recognized the economic contribution of business and convention tourism, and tapped the potential of business center regional and suburban conference tourism and professional exhibitions. Actively promote regional development business conferences and professional exhibition tourism with obvious traffic advantages and rich tourism resources.

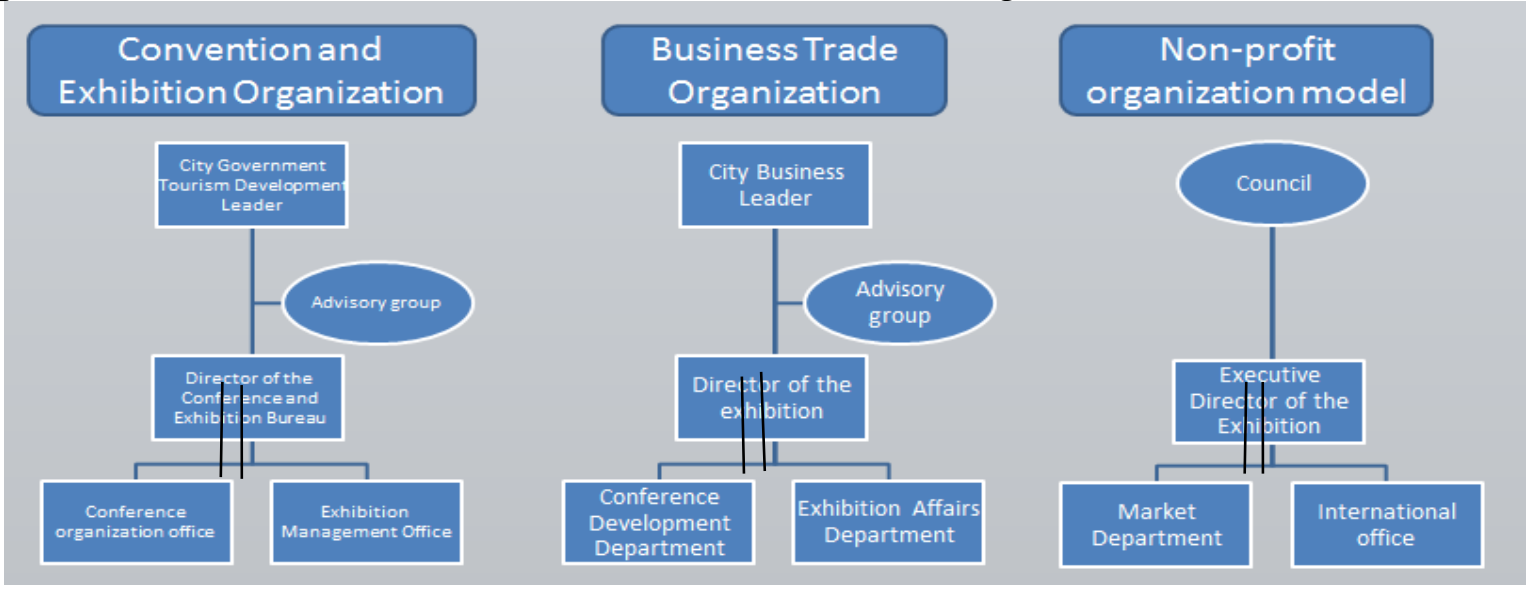




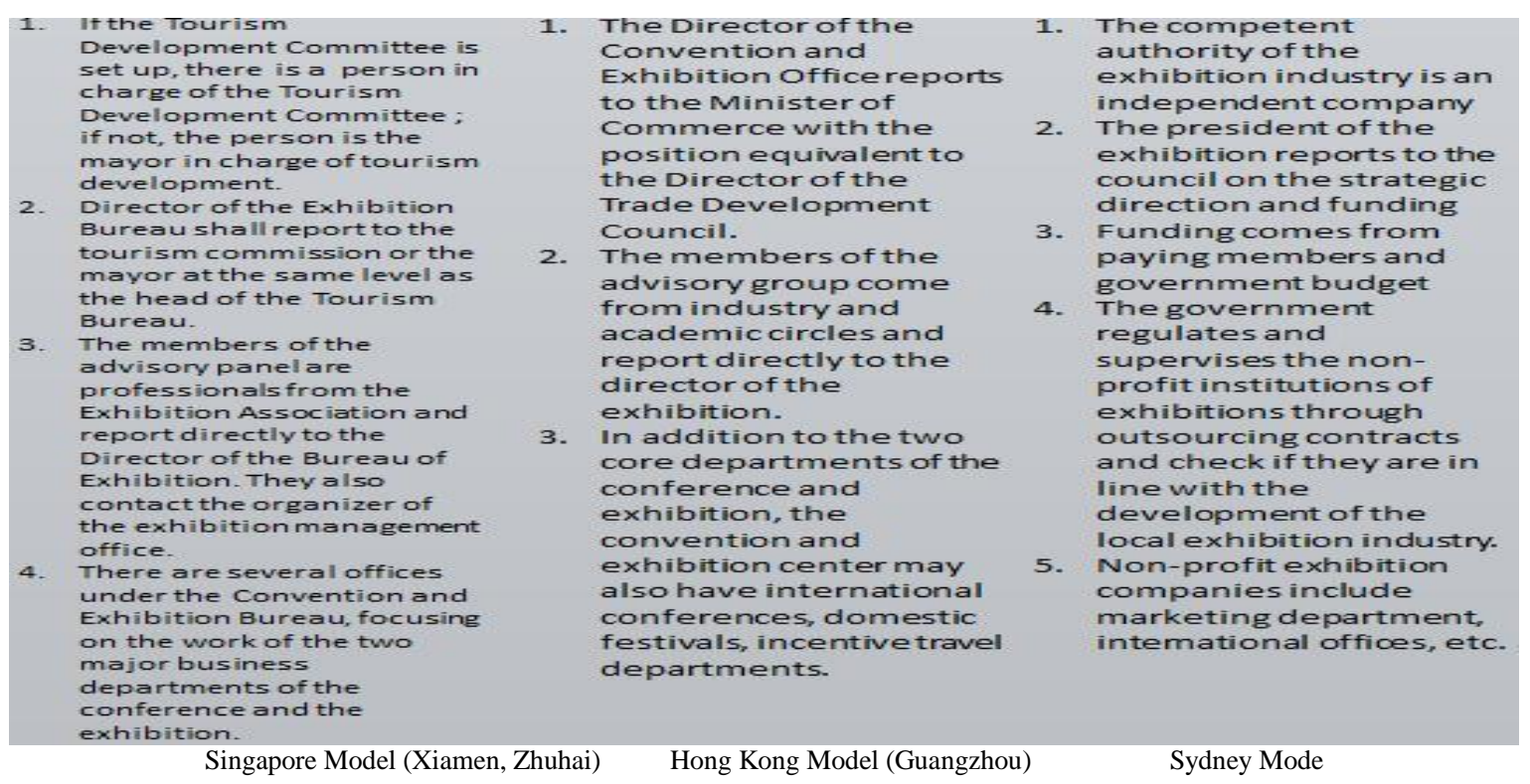

Figure 3. Organizations of Exhibition Management Units

Secondly, Guangzhou might draw on the experience of Sichuan and Xinjiang to enhance the status of the "Exhibition Office", reconstruct the management functions of the convention and exhibitions, and to establish the "Convention and Exhibition Bureau" related to the Canton Fair. In short, Guangzhou will have professional units to organize exhibition approval and exhibition promotion, and plan and formulate relevant exhibition tourism policies (including restaurants, hotels, scenic spots, theme entertainment centers and business centers) which is conducive to unified management, focusing on promoting the traditional advantages of the convention and exhibition industry. It is to considering establishing a regular business and conference and exhibition advisory group and strengthening the association's ties with the government will help solve major problems and avoid pitfalls in development.

In addition, it may respond to the call of the National Tourism Administrations and refer to Hong Kong, Zhuhai, and Xiamen modes. By reforming the functions of Guangzhou Tourism Administrations, the Tourism Administrations of Guangzhou has jurisdiction over the exhibition management functions of the original Commerce Commission, reshaping the functions of the tourism management agencies, and setting up a "Meeting and Exhibition Bureau" that is equivalent to the Tourism Bureau to vigorously develop the potential advantages of the Guangzhou conference industry. On the one hand, to join the international conference organization to support the conference delegates to host the world's major bid for the conference; on the other hand, continue to integrate large-scale exhibition resources and increase the use of the existing exhibition center. Because of the higher influence from Exhibition Office, this is of little possibility.

At the same time, with suburban professional exhibitions and conference centers as reception units, Guangzhou actively guided the creation of suburban business tourism circles and business tourism service areas, laying a solid foundation for conference reception and professional exhibitions. Finally, funding for Professional Employment Organization (PEO) ,to organize and service international exhibitions, support professionals to set up Professional Conference Organizer (PCO), and strengthen international conferences in Guangzhou. Although there is no professional Destination Management Company (DMC), the government departments themselves are forming a complete marketing service system to promote the full competition of the convention and exhibition industry.

Guangzhou is a major conference market and international exhibition city in China. Currently, it is striving to move towards the goal of becoming an international conference city and strive to build an international tourist destination. The related discussion about Guangzhou's practice in this article also has some enlightenment significance for the traditional trade center, the exhibition city, and the tourism city dedicated to attracting a large number of business travelers. 


\section{Acknowledgements}

This paper was sponsored by the Guangdong Provincial Department of Transportation Science and Technology Project (2015-02-064), and Doctorial Program of Zhaoqing University

\section{References}

[1] Adejiang.DAWUT, The Innovation and Industry Upgrading of MICE industry in Xinjiang, Journal of Xinjiang University of Finance and Economics, 2013(4): 35-40

[2] LUO Qiuju, TONG Juanjuan, Research on the Communication Effect of Mega-events on National Image Cognition: Based on Agenda-setting Theory. Tourism Tribune. 2014, 29 (6): 46-56

[3] XIE Gui-hua, JI Xiao-qing, XU An-xin. Innovation and Development of Fujian Convention and Exhibition Industry under the New Norm. Journal of Put ian University. 2015(4): 40-44.

[4] ZHAO Zhonghua, Wang Chunlei, Quan Hua. Research on the application of public-private partnership in tourism destination marketing -- based on cases in Amsterdam and Shanghai [J].Human Geography. 2014 (3):135-142

[5] WANG Chunlei, Feng Qi. Analysis on the migration strategy of foreign brand exhibitions -taking Expo Real China 2004 as an example [J].Tourism Tribune, 2005(2): 61-65 